\title{
Sistem Prediksi untuk Menentukan Jumlah Pendaftaran Mahasiswa Baru pada Unversitas Catur Insan Cendekia Menggunakan Metode Least Square
}

\author{
Humam Muhadzdzab ${ }^{1}$, Marsani Asfi ${ }^{2}$, dan Tiara Eka Putri ${ }^{3}$ \\ Fakultas Teknologi Informasi, Universitas CIC, Jln. Kesambi No. 202, Cirebon 45133 \\ e-mail: 1'humamfumi46@gmail.com, ${ }^{2}$ marsani.asfi@cic.ac.id, ${ }^{3}$ tiara.ucic@gmail.com \\ Submitted Date: August $25^{\text {th }}, 2020$ \\ Reviewed Date: September 22 $2^{\text {nd }}, 2020$ \\ Revised Date: September $28^{\text {th }}, 2020$ \\ Accepted Date: September $30^{\text {th }}, 2020$
}

\begin{abstract}
The prediction system for determining the number of prospective new students aims to make decisions and prioritize how many new students will be accepted and as a means of enthusiasts for the most study program trends each year, in making a prediction system, a method for good calculations is needed, so it is necessary method for the prediction system. This prediction system uses the Least Square method for the calculation of prediction results for system design carried out with an object-oriented approach using UML. The computer-based system built is web-based using the programming languages PHP and MySQL. From this research, the Least Sqaure method can be implemented to calculate predictions to determine the number of prospective new student registrations and to help the secretariat staff in the admissions section to find out the most interest in the study program each year.
\end{abstract}

Keywords: System; prediction; Registration; Student; Least-Square.

\begin{abstract}
Abstrak
Sistem prediksi untuk mengetahui jumlah calon mahasiswa baru adalah salah satu upaya untuk mengetahui bagaimana prioritas atau berapa banyak jumlah calon mahasiswa baru yang akan diterima dan sebagai sarana peminat trend prodi terbanyak pada setiap tahunnya, dalam membuat sistem prediksi sangat diperlukanya sebuah metode untuk perhitungan yang baik, sehingga diperlukannya suatu metode untuk sistem prediksi tersebut. Sistem prediksi ini menggunkan metode Least Square untuk perhitungan hasil prediksi. Pada penelitian ini jenis perancangan sistem yang digunakan adalah UML. Sistem berbasis komputer yang dibangun adalah web sistem prediksi dengan metode Least Square yang dibangun dengan bahasa pemrograman PHP dan MariaDB. Dari penelitian ini yang telah dilakukan, maka sistem dapat mengimplementasikan metode Least Sqaure untuk menghitung prediksi menentukan jumlah pendaftaran calon mahsiswa baru dan membantu pihak staff sekretariat pada bagian penerimaan mahasiswa baru untuk mengetahui peminatan terbanyak program studi setiap tahun.
\end{abstract}

Kata Kunci: Sistem; prediksi; Pendaftaran; Mahasiswa; Least-Square.

\section{Pendahuluan}

Universitas Catur Insan Cendekia (CIC) adalah perguruan tinggi yang menyelenggarakan program Sarjana Strata I (S1) dan Diploma III (D3) yang berlokasi di Jl. Kesambi No. 202 Kota Cirebon. Calon mahasiswa baru di Universitas Catur Insan Cendekia berasal dari dalam Kota Cirebon atau luar daerah dikarenakan setiap tahunnya Universitas Catur Insan Cendekia (CIC) melakukan pengenalan program studi ke sekolah baik dalam maupun luar kota Cirebon. Pada setiap kunjungan ke sekolah tersebut, bagian Marketing melakukan pendataan minat calon mahasiswa yang tertarik untuk mendaftar ke Universitas CIC. Data tersebut menjadi sumber awal untuk mengetahui sejauh mana minat siswa-siswa untuk bisa melanjutkan ke proses pendaftaran sampai dengan registrasi sehingga dapat dinyatakan sebagai mahasiswa di Universitas CIC. Berdasarkan permasalahan tersebut, dibutuhkan suatu sistem prediksi untuk menemukan jumlah pendaftaran calon mahasiswa baru di Universitas CIC dengan 
tujuan untuk mengambil keputusan dan mengetahui seberapa banyak jumlah mahasiswa baru yang akan mendaftar pada tahun akademik yang akan datang.

Sistem adalah kumpulan/group dari sub sistem/bagian/komponen apapun baik fisik ataupun non fisik yang saling berhubungan satu sama lain dan bekerja sama secara harmonis untuk mencapai satu tujuan tertentu (Modim dkk, 2018). Dalam situasi itu peramalan diperlukan untuk menetapkan kapan suatu peristiwa akan terjadi atau timbul, sehingga tindakan yang tepat dapat dilakukan. Peramalan merupakan alat bantu yang penting dalam perencanaan yang efektif dan efesien(Hariri, 2016). Membuat Sistem prediksi penentuan jumlah pendaftaran calon mahasiswa baru membutuhkan sebuah metode prediksi atau peramalan dan perhitungan yang baik. Dalam penelitian kali ini, metode yang akan diambil adalah metode Least Square. Metode Least Square (kuadrat terkecil) merupakan salah satu metode berupa data deret berkala yang mana dibutuhkan data-data dimasa lampau untuk melakukan memprediksi dimasa mendatang sehingga dapat ditentukan hasilnya (Hariri, 2016). Sangat penting untuk menggunakan data historis dengan menetapkan model matematis yang tepat agar dapat dijadikan informasi yang berguna(Senitio et al., 2018). Metode Least Square merupakan teknik pengoptimalan matematika (Chi H., 2015). Persamaan matematis dibentuk oleh metode kuadrat terkecil (Wan H. and Fan S. 2015). Jadi metode least square merupakan metode yang digunakan untuk melakukan suatu prediksi dengan memanfaatkan data histori masa lalu untuk dijadikan pedoman di masa depan.

\section{Metode penelitian}

\section{A. Prosedur Penelitian}

Prosedur yang digunakan dalam penelitian ini menggunakan metode pendekatan RAD yaitu Analisis Persyaratan, Perancangan sistem baru (Pemodelan) dan Implementasi atau membangun sistem yang digambarkan pada gambar berikut :

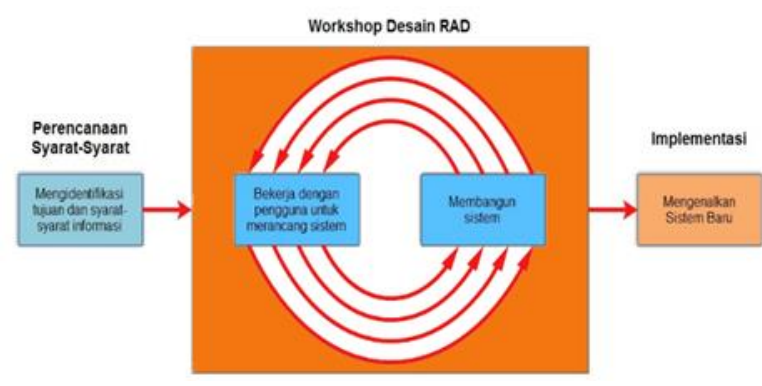

Gambar 1. Model RAD

Rapid Application Development (RAD) merupakan versi adaptasi cepat dari model waterfall, dengan menggunakan pendekatan konstruksi komponen. Model Rapid Application Development (RAD) dalam pengembangan sistem dapat dilakukan dalam waktu yang relatif lebih cepat( Putri and Effendi, 2018).

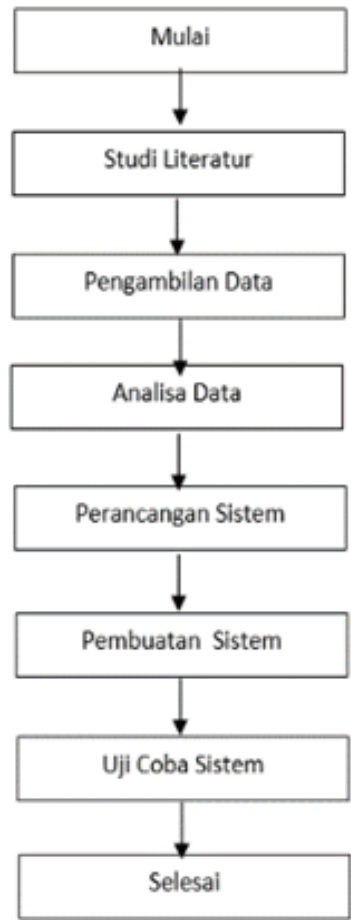

Gambar 2. Prosedur Alur Penelitian

Keterangan Gambar pada prosedur penelitian:

1. Studi Literatur

Pada tahap ini mempelajari teori-teori tentang sistem prediksi untuk menentukan jumlah pendaftaran mahasiswa baru menggunakan metode metode Least Square. kemudian melakukan tinjauan pustaka terhadap penelitian prediksi yang sama.

2. Pengambilan Data

Data jumlah mahasiswa baru yang digunakan untuk penelitian ini merupakan data pendaftaran atau jumlah mahasiswa yang mendaftar dan sudah melakukan registrasi diambil data dari 3 sampai 5 tahun terakhir dimulai dari periode tahun 2020.

3. Analisa Data

Pada tahapan ini data-data yang diperoleh akan digunakan sebagai konsep rancangan dalam pembuatan sistem prediksi.

4. Perancangan Sistem 
Pada tahap ini perancangan akan dilakukan pemodelan basis data, tampilan aplikasi dan alur metode least square untuk sistem prediksi yang digunakan.

\section{Pembuatan Sistem}

Setelah dibuat diagram UML, alur perhitungan metode Least Square, dan tampilan interface. Maka langkah selanjutnya adalah membuat sistem prediksi jumlah mahasiswa berbasis web.

\section{Uji Coba Sistem}

Setelah sistem prediksi selesai diimplemetasi maka selanjutnya uji coba sistem. Uji coba yang dilakukan meliputi uji coba menggunakan metode blackbox testing yaitu menguji proses sistem berdasarkan tampilan form sistem untuk input output. Selain itu juga dilakukan uji coba hasil prediksi data pendaftaran mahasiswa.

\section{B. Pengumpilan Data}

Pengumpulan data yaitu dengan mencari teori-teori terkait dengan sistem prediksi untuk menentukan jumlah mahasiswa baru dilihat baik dari buku, internet, website, pihak institusi. Adapun studi lapangan yang dilakukan adalah :

1. Observasi

Pengamatan dilakukan dengan melakukan kunjungan langsung di Universitas Catur Insan Cendekia yaitu kepada staf marketing dan bagian bidang kemahasiswaan. Tujuan dilakukannya observasi guna mengetahui bagaimana jalannya sistem yang akan dibuat dalam mengetahui data yang diperlukan. Kemudian dari masalah yang telah didapat akan dilakukan analisis untuk mengembangkan sistem prediksi pada Universitas Catur Insan Cendekia.

\section{Wawancara}

Pada pengumpulan data ini, akan dilakukan wawancara langsung kepada bagian marketing CIC untuk mendapatkan data-data yang akan diperlukan untuk melakuan pembuatan sistem prediksi ini.

\section{Studi Literatur}

Teknik pengumpulan data dengan mengumpulkan dokumen dari pihak akademik maupun referensi dari perpustakaan terkait dengan pembuatan sistem prediksi untuk menentukan jumlah pendaftaran mahasiswa baru.

\section{Metode Least Square}

Metode Least Square (kuadrat terkecil) merupakan salah satu metode berupa data deret berkala yang mana dibutuhkan data-data dimasa lampau untuk melakukan peramalan dimasa mendatang sehingga dapat ditentukan hasilnya.
Metode least square merupakan metode yang paling sering digunakan untuk meramalkan besar variabel dalam runtut waktu tertentu. Persamaan garis trend yang akan dicari ialah:

$$
\begin{aligned}
& \mathrm{Y}=\mathrm{a}+\mathrm{bX} \\
& \text { Di mana }: \mathrm{a}=\frac{\sum y}{n} \text { dan } \mathrm{b}=\frac{\sum x y}{\sum x^{2}} \\
& \text { dengan: } \\
& \mathrm{Y}=\text { data berkala atau data yang selalu } \\
& \text { berubah dalam kurun waktu tertentu = } \\
& \text { taksiran nilai trend. } \\
& \mathrm{a}=\text { nilai trend pada tahun dasar. } \\
& \mathrm{b}=\text { rata-rata pertumbuhan nilai trend tiap } \\
& \text { tahun. } \\
& \mathrm{X}=\text { variabel waktu (hari, minggu, bulan } \\
& \text { atau tahun) }
\end{aligned}
$$

Untuk melakukan penghitungan, maka diperlukan nilai tertentu pada variabel waktu(x) sehingga jumlah nilai variabel waktu adalah nol atau $\Sigma x=0$. Untuk n ganjil maka:

1. Jarak antara dua waktu diberi nilai satu satuan.

2. Di atas 0 diberi tanda negatif

3. Di bawahnya diberi tanda positif.

Untuk n genap maka :

1. Jarak antara dua waktu diberi nilai dua satuan

2. Di atas 0 diberi tanda negatif.

3. Di bawahnya diberi tanda positif.

\subsubsection{Analisis Prediksi dengan Metode Least Square}

Pada bagian ini akan dilakukan analisis data jumlah mahasiswa yang digunakan dimulai dari mempelajari tahapan-tahapan dalam metode least square. Tahapan dalam metode ini harus dilakukan secara bertahap. Adapun tahapan dalam metode ini

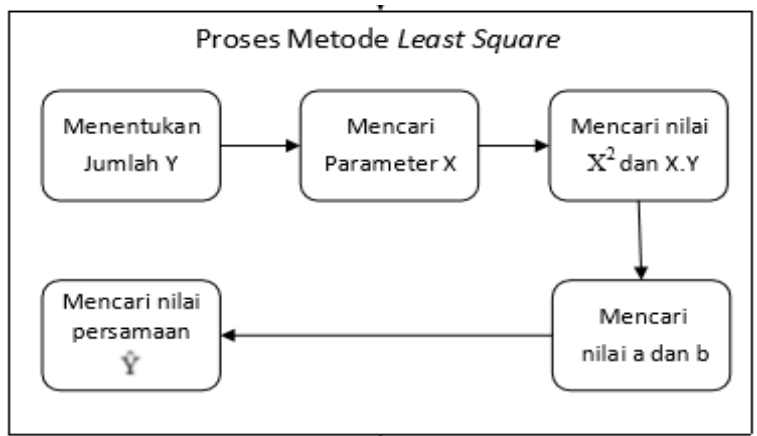

akan dijelaskan sebagai berikut:

Gambar 3. Proses Alur Metode Least Square

Keterangan:

a. Tentukan data jumlah pendaftar (Y) 
b. Tentukan parameter $\mathrm{X}$ Dalam menentukan parameter $\mathrm{X}$ jika jumlah data genap maka nilai $\mathrm{X}$ yang digunakan $-5,-31,1,3,5$ dan seterusnya tergantung jumlah data, sedangkan data ganjil 3,$2,-1,0,1,2,3$ dan seterusnya.

c. Tentukan nilai X2 dan X.Y Nilai X2 didapatkan dari hasil nilai $X$ dikuadratkan. Sedangkan untuk nilai X.Y merupakan perkalian dari nilai $X$ dengan Nilai Y.

d. Buat persamaan trend nilai a dan nilai $b$ untuk menentukan persamaan trend $\mathrm{a}$ dan $\mathrm{b}$ dengan $\begin{array}{lll}\text { rumus berikut: 1) } a \frac{\sum \mathrm{y}}{\mathrm{n}} & \text { 2) } b \frac{\sum \mathrm{y} \cdot \mathrm{x}}{\sum \mathrm{x} 2}\end{array}$

Di mana : $\Sigma \mathrm{Y}=$ Total jumlah aktual dari $\mathrm{Y}$ $\mathrm{n}=$ Jumlah data

$\Sigma$ Y.X $=$ Total jumlah perkalian $\mathrm{X}$ dan $\mathrm{Y}$ $\Sigma \mathrm{X}^{2}=$ Total jumlah kuadrat dari $\mathrm{X}$ $a=$ Nilai trend pada tahun dasar $b=$ Rata-rata pertumbuhan nilai trend pada tiap tahun

e. Menentukan nilai permsamaan trend "Ŷ" Untuk mencari permasamaan trend $\hat{Y}$ dengan rumus

berikut: $\quad \hat{\mathrm{Y}}=\mathrm{a}+\mathrm{b} .(\mathrm{X})(3)$

Di mana :

$\hat{Y}=$ nilai veriabel terikat (dependent variabel).

$a=$ Nilai trend pada tahun dasar

$b=$ Rata-rata pertumbuhan nilai trend pada tiap tahun $\mathrm{X}=$ nilai variabel bebas (independent variabel).

\section{Pengujian dan Pembahasan Sistem}

\section{A. Pengujian Data Aktual dan Prediksi}

Tabel 1. Tabel Aktual Data Mahasiswa yang Sudah Mendaftar

\begin{tabular}{|c|c|c|c|c|}
\hline \multicolumn{5}{|c|}{$\begin{array}{l}\text { FAKULTAS TEKNOLOGI DAN } \\
\text { INFORMASI }\end{array}$} \\
\hline $\begin{array}{l}\text { Tanun } \\
\text { Akademik }\end{array}$ & $T I$ & $S I$ & $D K V$ & Jumlah \\
\hline 2016 & 105 & 133 & 84 & 322 \\
\hline 2017 & 49 & 85 & 100 & 234 \\
\hline 2018 & 98 & 59 & 76 & 233 \\
\hline 2019 & 68 & 40 & 24 & 132 \\
\hline Jumlah & 320 & 317 & 284 & 921 \\
\hline
\end{tabular}

Jumlah data aktual calon mahasiswa baru yang akan mendaftar pada tahun akademik dari 2016 - 2019 maka untuk mencoba perhitungan manual menggunakan metode least square. sistem prediksi mencoba mengambil contoh perhitungan secara keseluruhan dari semua jurusan atau prodi yang sudah ada. Yaitu dimulai dari tahun akademik 2019 yang sudah diketahui data aktual (sebenarnya) untuk menghitung data prediksi hasilnya akan diketahui presentase dari data aktual (sebenarnya) dan data yang sudah diprediksi.

1. Perhitungan Prediksi Jumlah Calon Mahasiswa Baru secara global pada tahun akademik 2019.

Tabel 2. Tabel Perhitungan prediksi Pendaftaran 2019

\begin{tabular}{|c|c|c|c|c|}
\hline $\begin{array}{c}\text { Tahun } \\
\text { Pendaftaran }\end{array}$ & $(\mathrm{Y})$ & $X$ & X.Y & $\mathrm{X}^{2}$ \\
\hline 2016 & 322 & -3 & -966 & 9 \\
\hline 2017 & 234 & -1 & -234 & 1 \\
\hline 2018 & 233 & 1 & 233 & 1 \\
\hline 2019 & 132 & 3 & 396 & 9 \\
\hline Jumlah & 921 & 0 & \begin{tabular}{|l|}
-571 \\
\end{tabular} & 20 \\
\hline
\end{tabular}

Persamaan trand Menjadi:

$\hat{\mathrm{Y}}=\mathrm{a}+\mathrm{b} .(\mathrm{X})$

Dengan menggunakan persamaan tersebut, dapat diramalkan atau diprediksi pendaftaran mahasiswa baru pada tahun 2019 adalah :

$$
\begin{aligned}
& =230,25+(-28,55 * 3) \\
& =144,6
\end{aligned}
$$

Artinya perhitungan manual least square data prediksi yang didapat pada tahun 2019 jumlah mahasiswa yang akan mendaftarkan 144,6 dibulatkan 144 Orang.

Setelah mendapatkan hasil dari prediksi jumlah pendaftaran mahasiswa baru pada tahun akademik 2019 dapat dilihat pada Tabel 3.2 yaitu dengan hasil pendaftaran prediksi 144,6 maka akan dihitung penentuan error prediksi dengan menggunkan metode Mean Absolute Percentese Error (MAPE). Berikut Pengukuran kesalahan prediksinya pada tabel perhitungan berikut ini :

Tabel 3. Tabel Data Hasil Prediksi Dengan Data Sebenarnya

\begin{tabular}{|c|c|c|c|}
\hline Tahun & $(\mathrm{Y} 1)$ & $(\mathrm{Y} 2)$ & $\begin{array}{c}\text { MAPE } \\
\text { Y1Y2)/Y1 }\end{array}$ \\
\hline 2016 & 322 & 315,9 & 0,0189 \\
\hline 2017 & 234 & 258,8 & 0,106 \\
\hline 2018 & 233 & 201,7 & 0,1343 \\
\hline 2019 & 132 & 144,6 & 0,0955 \\
\hline \multicolumn{3}{|l}{} & 0,3547 \\
\hline
\end{tabular}


a. Berikut ini merupakan penentuan erorr prediksi dengan menggunakan Mean Absolute Percentace Error (MAPE) adalah sebagai berikut:

$$
\begin{aligned}
\text { MAPE } & =\frac{\sum(y 1-y t) x^{2}}{-\frac{y 1}{n}} X \times 100 \% \\
& =\frac{\sum 0,3546}{4} \times 100 \% \\
& =8,87 \%
\end{aligned}
$$

Maka perhitungan errornya prediksi pada tahun akademik 2019 sebesar 8,87\%. Dengan nilai error prediksi yang semakin kecil maka hasil prediksinya semakin akurat. Sehingga metode least square dapat digunakan untuk sistem prediksi menentukan jumlah mahasiswa baru tahun akademik yang datang.

2. Presentase Data Aktual dengan Data Prediksi.

Tabel 4. Tabel Presentase Data Sebenarnya dengan Prediksi

\begin{tabular}{|c|c|c|c|}
\hline Tahun & Aktual & Prediksi & Selisih \\
\hline 2019 & 132 & 144,6 & 12,6 \\
\hline
\end{tabular}

Setelah mendapatkan hasil dari data prediksi jumlah calon pendaftaran mahasiswa baru pada tahun akademilk 2019 di Universitas CIC, dengan data aktual 132 orang dan hasil dari data prediksi 144 orang calon mahasiswa baru. Selisih antara data prediksi dengan data sebenarnya adalah sebesar 12,6\%, jadi untuk presentase jumlah mahasiswa baru pada tahun 2019 dengan mengggunakan sistem prediksi menggalami kenaikan dari data yang sebenarnya. Perhitungan Prediksi Jumlah Calon Mahasiswa Baru secara global pada tahun akademik 2020.

Tabel 5. Tabel Perhitungan prediksi Pendaftaran 2020

\begin{tabular}{|c|c|l|l|l|}
\hline $\begin{array}{c}\text { Tahun } \\
\text { endaftaran }\end{array}$ & $\begin{array}{c}\text { Jumah Calon } \\
\text { Mahasiswa (Y) }\end{array}$ & X & X.Y & $X^{2}$ \\
\hline 2016 & 322 & -3 & 966 & 9 \\
\hline 2017 & 234 & -1 & 234 & 1 \\
\hline 2018 & 233 & 1 & 233 & 1 \\
\hline 2019 & 132 & 3 & 396 & 9 \\
\hline Jumlah & 921 & 0 & 571 & 20 \\
\hline
\end{tabular}

Di mana: a $\frac{\sum \mathrm{y}}{\mathrm{n}}=\frac{921}{4}=230,25$

$$
\mathrm{b} \frac{\sum \mathrm{y} \cdot \mathrm{X}}{\sum \mathrm{x} 2}=\frac{-571}{20}=-28,55
$$

Persamaan trand menjadi:

$$
\hat{\mathrm{Y}}=\mathrm{a}+\mathrm{b} .(\mathrm{X})
$$

Dengan menggunakan persamaan tersebut, dapat diramalkan atau diprediksi pendaftaran mahasiswa baru pada tahun 2020 adalah:

$$
\begin{aligned}
& =230,25+(-28,55 * 5) \\
& =87,5
\end{aligned}
$$

Artinya perhitungan manual least square data prediksi yang didapat pada tahun akademik 2020 jumlah mahasiswa yang akan mendaftarkan 87,5 dibulatkan 87 Orang.

Jadi untuk perhitungan manual data prediksi menentukan jumlah mahasiswa baru pada tahun berikutnya yaitu mendapatkan jumlah data prediksi 87,5 dibulatkan 8,7 dengan mengalami penurunan dari data prediksi tahun 2019. Pada tahun akademik 2020 tidak dapat mengukur tinggat kesalahan prediksi Mean Absolute Percentage Error (MAPE) karena tidak ada data aktul (sebenarnya) untuk prediksi tahun 2020.

\section{Kesimpulan}

Berdasarkan hasil pembahasan sistem prediksi untuk menentukan jumlah pendaftaran mahasiswa baru pada Universitas Catur Insan Cendekia menggunakan metode Least Square yang telah dilakukan, maka dapat disimpulkan sebagai berikut:

1. Sistem prediksi mahasiswa baru dengan menggunakan metode Least Square merupakan aplikasi yang dapat digunakan sabagai proses untuk menghitung jumlah penentu mahasiswa baru yang akan mendaftar di Universitas CIC.

2. Hasil dari penerapan metode Least Square untuk menghitung jumlah mahasiswa yang akan mendaftar dapat diperoleh nilai prediksi yang sudah ditentukan. Data tersebut sabagai informasi dalam mempersiapkan proses pembelajaran atau sabagai peminataan pada setiap prodi.

Dari hasil perhitungan prediksi pada tahun akademik 2019 sebesar 8,87\%. Dengan nilai error prediksi yang semakin kecil maka hasil prediksinya semakin akurat. Sehingga metode least square dapat digunakan untuk sistem prediksi menentukan jumlah mahasiswa baru di masa yang akan datang.

\section{Referensi}

Arif R. M., Jantje J. Tinangon, S. P. (2018). 3 1,2,3. 13(4), 776-785.

Chi H., 2015. A Discussions on the Least-Square Method in the Course of Error Theory and Data 
Processing. International Conference on Computational Intelligence and Communication Networks A, pp.486-489. DOI : 10.1109/CICN.2015.100.

Ge L., Ye S Y., Shan S T., Zhu S H., Wan H. and Fan S. 2015., The Model of PK/PD for Danhong Injection Analyzed by Least Square Method. International Conference on Information Technology in Medicine and Education, pp.292296. DOI: 10.1109/ITME.2015.47.

Hariri, F. R. (2016). Metode Least Square Untuk Prediksi Penjualan Sari Kedelai Rosi. Simetris : Jurnal Teknik Mesin, Elektro Dan Ilmu Komputer, 7(2), 731. https://doi.org/10.24176/simet.v7i2.788

Helmiah, F. (2020). Implementation of Least Square Method for Sales. JURIKOM (Jurnal Ris. Komputer) , 2(2), 13-18.

Pamungkas, D. P. (2016). Implementasi Metode Least Square Untuk Prediksi Penjualan Tahu Pong. Jurnal Ilm. NERO, 2(2), 75-81.
Putri and H. Effendi, Implementasi Metode Rapid Application Development Pada Website Service Guide Waterfall Tour South Sumatera, $J$. SISFOKOM, vol. 07, no. September, pp. 130-136, 2018.

Putri, M. P., \& Effendi, H. (2018). Implementasi Metode Rapid Application Development Pada Website Service Guide "Waterfall Tour South Sumatera." Jurnal SISFOKOM, 07(September), 130-136.

Senitio, G. B., Santony, J., \& Na'am, J. (2018). Tingkat Prediksi Pendaftar Ujian Kompetensi Laboratorium Menggunakan Metode Least Square. Jurnal RESTI (Rekayasa Sistem Dan Teknologi Informasi), 2(3), 746-752. https://doi.org/10.29207/resti.v2i3.530

Suwita, M. M. L. (2018). Metode Least Square dalam Mengukur Trend Penjualan Pada Home Industry Bengkel Sendal Thostee Bukittinggi. Jurnal Menara Ilmu , 7(79), 45-61. 